\title{
Effect of lignin and hemicelluloses on the tensile strength of micro-veneers determined at finite span and zero span
}

\author{
André Klüppel and Carsten Mai* \\ Wood Biology and Wood Products, Burckhardt-Institute, \\ Georg August University of Göttingen, Büsgenweg, \\ Göttingen, Germany \\ * Corresponding author. \\ Wood Biology and Wood Products, \\ Burckhardt-Institute, \\ Georg August University of Göttingen, \\ Büsgenweg 4, 37077 Göttingen, \\ Germany \\ Phone: +49-551-3919807 \\ Fax: +49-551-399646 \\ E-mail: cmai@gwdg.de
}

\begin{abstract}
Scots pine micro-veneers were subjected to hydrolysis with sulphuric acid or delignification with acidic sodium chlorite and a combination of both treatments. The tensile strength of untreated and treated veneers was determined at finite span (f-strength) and zero span (z-strength) under both dry $\left(20^{\circ} \mathrm{C}\right.$, $65 \%$ relative humidity) and water-saturated conditions. Acidic hydrolysis resulted in significant strength losses in both testing modes and both moisture conditions, with the greatest strength reduction found for f-strength tested dry. After delignification, only f-strength under wet conditions was substantially reduced; dry f-strength and both dry and wet z-strength hardly changed. A combined treatment of prehydrolysis and delignification resulted in disintegration of the veneers, which made strength determination impossible. It was concluded that, in addition to cellulose, the hemicelluloses determine the f-strength under dry conditions, while lignin confers wet strength but appears not to contribute to interfibre adhesion and f-strength under dry conditions.
\end{abstract}

Keywords: dry strength; finite span; microtensile testing; micro-veneers; wet strength; zero span.

\section{Introduction}

The tensile strength of an individual wood cell is mainly determined by cellulose. The higher the degree of polymerisation (DP) the higher is the tensile strength of a fibre or tracheid (Winandy and Rowell 1984). Two principle techniques based on thin veneer strips have been described to assess the tensile strength of wood (Figure 1). In conventional microtensile tests, the jaws for fixing the specimens (paper handsheet, veneer) have a finite span (f-span), while at zero span (z-span) testing, the jaws directly touch each other. In the latter case, the wood is not subjected to shear stress between the fibres (Law et al. 1977). The failure of veneers tested at z-span is therefore solely the result of intrafibre fracture while specimens failing at f-span testing do so as a result of both intraand inter-fibre fractures (Evans and Banks 1988). Decrease in tensile strength measured as z-strength is therefore attributable to damage to cellulose, i.e., to reduction in its DP, while f-strength is influenced by degradation of the matrix material, i.e., hemicelluloses and lignin (Derbyshire et al. 1995; Xie et al. 2007).

Microtensile testing is used to evaluate wood degradation during weathering (Raczkowski 1980; Derbyshire and Miller 1981; Evans et al. 1992, 1996; Derbyshire et al. 1995, 1996, 1997; Turkulin et al. 2004) and microbial decay, to assess the effectiveness of wood preservatives (Hartley 1958; Haider and Domsch 1969; Bravery and Grant 1971). Strength losses attributable to chemical modification of wood can also be monitored by microtensile testing (Xie et al. 2007, 2010; Xiao et al. 2010).

The aim of this study is to determine the effects of hydrolysing polysaccharides and removing lignin on the tensile strength of micro-veneers measured under dry and wet conditions.

\section{Materials and methods}

\section{Specimen preparation}

Micro-veneers measuring $50 \mathrm{~mm} \times 15 \quad \mathrm{~mm} \times 80 \quad \mu \mathrm{m}$ (length $\times$ width $\times$ thickness) were cut from two Scots pine (Pinus sylvestris L.) sapwood blocks saturated in aqueous ethanol (10\% by volume) as previously described (Evans and Banks 1988). One hundred and twenty veneers from each block were then divided into four groups of 30 veneers each, according to a $2^{2}$-factorial design, with acid hydrolysis and delignification being the factors. Veneers from different wood blocks were treated separately; however, the wood block from which each sample originated did not significantly influence the results, so we did not consider this factor in the analysis.

To hydrolyze amorphous polysaccharides, each of the respective groups of veneers was stored in an Erlenmeyer flask with $200 \mathrm{ml}$ of $0.5 \mathrm{M}$ sulphuric acid for $4 \mathrm{~h}$ at $80^{\circ} \mathrm{C}$. The other veneers were stored under the same conditions in demineralised water. Then the sulphuric acid was decanted, the veneers rinsed three times with demineralised water, and $160 \mathrm{ml}$ of demineralised water added to each flask; the flasks were then kept at $80^{\circ} \mathrm{C}$ for $30 \mathrm{~min}$.

For delignification, $0.5 \mathrm{ml}$ of glacial acetic acid and $1.5 \mathrm{~g}$ of sodium chlorite were added. The veneers were kept in this solution for $4 \mathrm{~h}$, with the same amounts of chemicals being added after 1,2 and $3 \mathrm{~h}$ and the flasks gently shaken. The veneers were then removed and rinsed with demineralised water (Browning 1967). After treatment, one half of the veneers were kept in water, and the other half conditioned at $20^{\circ} \mathrm{C}$ and $65 \%$ relative humidity (RH). 


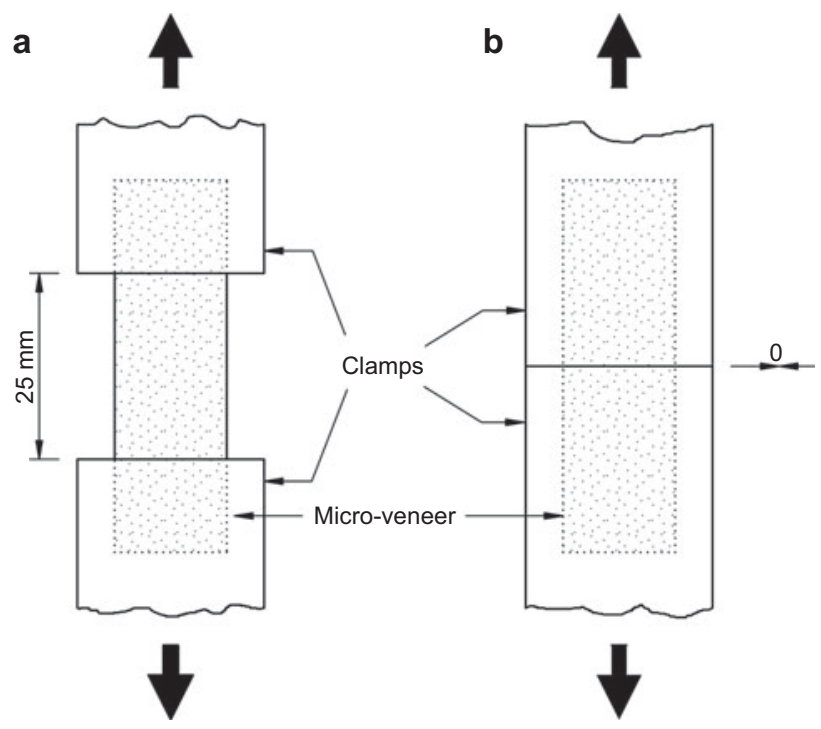

Figure 1 Adjustment of jaws at the determination of microtensile strength. (a) Finite span (span: $25 \mathrm{~mm}$ ); (b) zero span. Arrows show the direction of the tensile force.

\section{Micro-tensile testing}

Zero span tensile strength was assessed with a Pulmac paper tester (Pulmac International Inc., Montpelier, VT, USA) as described previously (Derbyshire and Miller 1981; Evans and Schmalzl 1989; Xie et al. 2007). The clamping pressure was set to 5.5 bar and the force gradually increased by $2.76 \mathrm{~N} \mathrm{~s}^{-1}$. Five veneers were tested per treatment, moisture condition, and wood block; two measurements were performed on each veneer. Conventional f-strength was measured with the tensile testing machine $\mathrm{Z} 3$ (Thümler GmbH, Nürnberg, Germany) with a free clamping length of $25 \mathrm{~mm}$ and a testing speed of $1 \mathrm{~mm} \mathrm{~s}^{-1}$. The elongation was set to zero at a (pre)force of $1 \mathrm{~N}$. Ten veneers were tested per treatment, moisture condition, and wood block.

\section{Infrared spectroscopy}

Fourier-transform infra-red (FT-IR) spectra of conditioned $\left(20^{\circ} \mathrm{C}\right.$, $65 \% \mathrm{RH})$ micro-veneers were recorded by means of the attenuated total reflection (ATR) technique (DuraSamplIRII, SensIR Technologies, Warrington, UK), using a Vektor 22 spectrophotometer (Bruker, Bremen, Germany) (64 scans, $4 \mathrm{~cm}^{-1}$ resolution). Background spectra were collected with the empty ATR unit. The baseline correction was made using the rubber band method in the OPUS software (Bruker, Bremen, Germany). All spectra were normalised to absorption of $2 \mathrm{Au}$ at the highest peak at approximately $1030 \mathrm{~cm}^{-1}$. Ten spectra from each group were averaged.

\section{Results and discussion}

Successful delignification of the veneers was assessed by FT-IR spectroscopy; however, absorption at $1505 \mathrm{~cm}^{-1}$ attributable to aromatic stretch vibration (Faix et al. 1992) indicated a minor content of residual lignin (Figure 2). This is in accordance with Browning (1967), who found a residual lignin content of 2-4\% after delignification. Hydrolysis with sulphuric acid decreased the absorption around $1750 \mathrm{~cm}^{-1}$, which is attributed to xylans (Harrington et al. 1964), while absorptions assigned to glucomannans at $805-810 \mathrm{~cm}^{-1}$ and $870 \mathrm{~cm}^{-1}$ (Harrington et al. 1964) were left unchanged. The absorption band in the region of $1275 \mathrm{~cm}^{-1}$, which is attributed to lignin, exhibits a shoulder $\left(1240 \mathrm{~cm}^{-1}\right)$ assigned to xylan. Consequently, absorption in this area was lower after hydrolysis and delignification than after delignification alone.

Under wet conditions, the ultimate strength of the microveneers measured at $\mathrm{z}$-span was greater than that of those conventionally (f-span) measured (Figure 3 ). This is because the probability of subjecting a weak point in a cell wall to maximum stress is reduced in z-span testing (Law et al. 1977). Lower f-strength than $\mathrm{z}$-strength was previously reported also for measurements performed under dry conditions (Law et al. 1977; Derbyshire et al. 1995).

The softness of the wet delignified veneers made it impossible to determine their thickness precisely and the ultimate stress was therefore not assessed. The f-strength ${ }_{\text {wet }}$ was significantly lower than that of the dry specimens, while the z-strength ${ }_{\text {dry }}$ was the same, and z-strength ${ }_{\text {wet }}$ was even slightly higher than f-strength dry . Tensile strength reduction (f-strength) with increasing moisture content between $8 \%$ and fibre saturation point is well known (Kollmann 1951). Bound water interferes with and reduces hydrogen bonding between the cell wall polymers (Winandy and Rowell 1984) and thus decreases the strength of wood.

During conventional tensile testing, an elastic area and a plastic area of elongation can be distinguished. In the former, hydrogen bonds between and within individual polysaccharides and between adjacent microfibrils are breaking, sliding and subsequently reforming (Winandy and Rowell 1984). Individual cell wall layers and whole cells are reversibly distorted in relation to one another. Above the proportional

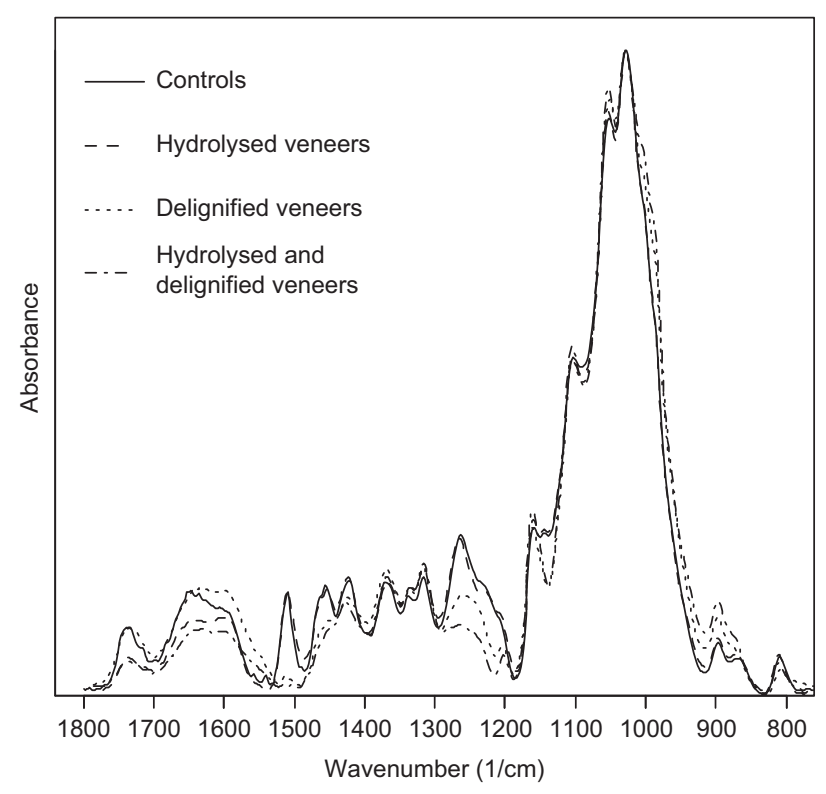

Figure 2 FT-IR spectra of acid-treated, delignified and watertreated micro-veneers. The spectra were recorded at conditioned $\left(20^{\circ} \mathrm{C}, 65 \%\right.$ relative humidity) micro-veneers. 
limit (plastic elongation) covalent bonds are breaking and the DP of cellulose is decreasing. Individual cell wall layers and whole cells are irreversibly distorted and translocated in relation to one another (Ifju 1964; Winandy and Rowell 1984). At z-span testing, the individual cells and cell wall layers are fixed from both sides and thereby distortion and translocation of these elements do not occur.

Acidic hydrolysis significantly reduced the tensile strength in both moisture states (Figure 3). Among the conditioned veneers, the loss in f-strength was more pronounced than that in z-strength. This may be because both cellulose and hemicelluloses contribute to f-strength, while only cellulose determines z-strength. Therefore hydrolysis of hemicelluloses leads to f-strength loss. When measured wet, the reduction in z-strength after hydrolysis was somewhat greater than the reduction in f-strength. Obviously, under wet conditions f-strength is mostly attributable to the DP of cellulose, while hemicelluloses appear to have a minor role.

Delignification influenced neither f-strength nor z-strength of the conditioned veneers but significantly reduced f-strength of veneers measured wet (Figure 3). This indicates that lignin does not directly influence the tensile properties of wood but increases wet strength and reduces the accessibility of water to the polysaccharides. The maximum strength of wet veneers was somewhat lower at $\mathrm{z}$-span measurement because of delignification. This corresponds to the results of Gurnagul and Page (1989) and Kersavage (1973). These authors found that even the strength of individual fibres is reduced by wetting when the interfibrillar matrix is chemically or mechanically damaged by pulping, bleaching or delignification. This reduction may partly be attributable to small deviation of the testing procedure from the ideal. The veneers tend to slip slightly out of the clamps, thereby forming a small gap (Cowan 2006). In this gap, the conditions are similar to those during f-span testing and weak points in the matrix may fail.

Veneers that were both hydrolysed and delignified disintegrated into fragments during rinsing, so that their tensile strength could not be measured. This shows that an interfibre failure occurs under low stress conditions and that hemicelluloses are mainly responsible for interfibre adhesion, while lignin imparts hydrophobation, i.e., wet strength.

During f-span testing, the veneers tended to rupture partly at the weak points such as ray cells. The resulting stress reduction led to a "jagged" stress-strain curve, which complicated the determination of the modulus of elasticity. Therefore the quotient of the strain at maximum force and the maximum force was used as a measure of pliability, which therefore includes elastic and plastic deformation (Figure 4). Under dry conditions, delignification increased pliability only slightly, while under wet conditions, delignified veneers were much more pliable than the wet controls. Hydrolysis had no effect on pliability as compared to the untreated veneers irrespective of the moisture conditions.

Previous studies (Evans and Banks 1988, 1990; Derbyshire et al. 1995) suggested that the tensile properties of wood depend significantly on the bonding ability of matrix materials under wet conditions. This effect is less pronounced under dry conditions. The present study shows that lignin determines wet

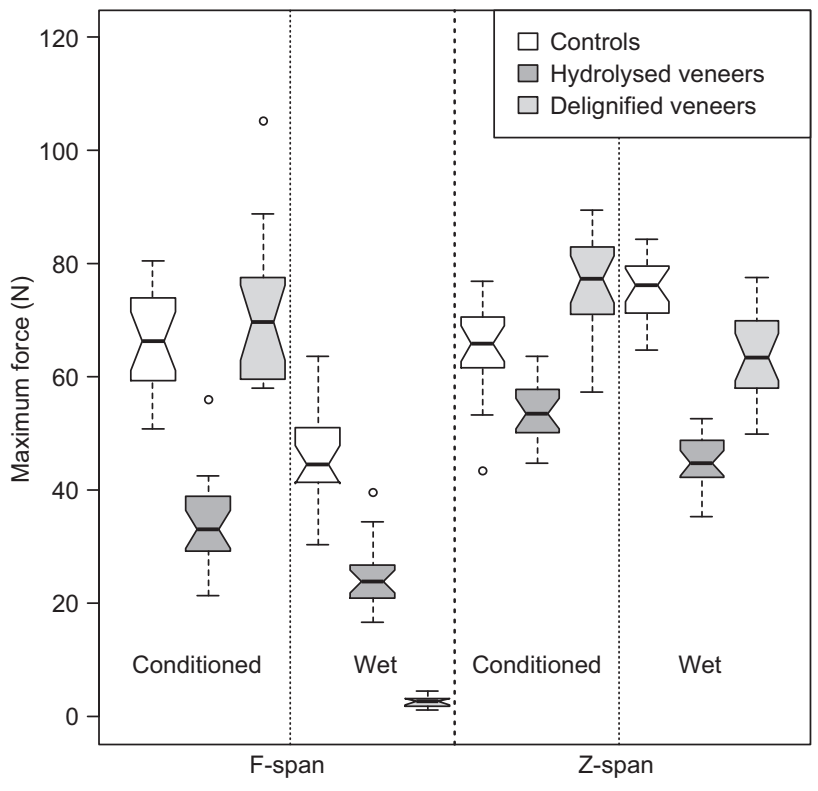

Figure 3 Ultimate tensile strength of differently treated microveneers. Water saturated (wet) or conditioned $\left(20^{\circ} \mathrm{C}, 65 \%\right.$ relative humidity) micro-veneers were tested at finite span (f-span) and at zero span (z-span). The notches indicate the $95 \%$ confidence interval of the median (McGill et al. 1978); non-overlapping confidence intervals indicate significant differences. Data points that are more than 1.5 times the interquartile range from the box are defined as outliers and displayed individually.

f-strength but not dry tensile strength irrespective of the testing mode. Hemicelulloses contributed significantly to f-strength under dry measuring conditions but lignin did not. Therefore diminution of f-strength under dry conditions is a result of the degradation of hemicelluloses rather than the degradation

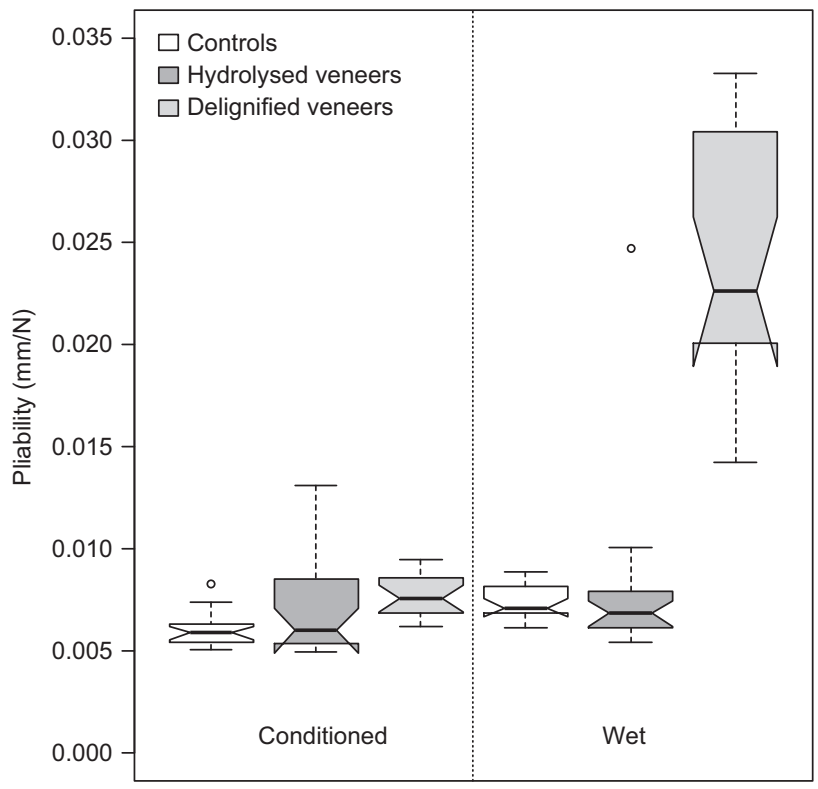

Figure 4 Pliability of micro-veneers determined as the quotient of the strain at maximum force and the maximum force assessed at f-span (see Figure 3). 
of lignin. The same is true for the shift from intrafibre (interlocked) failure to interfibre (brittle) failure under dry conditions that was previously shown (Turkulin and Sell 2002).

\section{Conclusion}

Damage to matrix materials in micro-veneers decreases wet strength at z-span and f-span, with f-strength being clearly more sensitive. Loss in dry strength measured in both modes is exclusively attributable to the breakdown of polysaccharides, particularly of cellulose. In addition to cellulose, the hemicelluloses determine the f-strength when this is measured dry. Lignin acts as a wet strength agent but appears not to contribute to interfibre adhesion and f-strength under dry conditions.

\section{Acknowledgements}

The authors received financial support from the Fachagentur Nachwachsende Rohstoff (Agency for Renewable Resources) (project no. 22004407). We wish to thank Patricia Gascón for supporting the experimental work.

\section{References}

Bravery, A.F., Grant, C. (1971) Preliminary investigations into the use of a thin strip tensile strength test for the rapid evaluation of wood preservatives against basidiomycete fungi. Int. Biodet. Bull. 7:169-173.

Browning, B.L. (1967) Methods of wood chemistry - Volume 2. New York: Interscience publishers.

Cowan, W.F. (2006) Fiber quality and testing: theory and practice. In: Pulmac Z-span 1000 Operation and Service Manual. Pulmac Inc, Pointe-Claire (QC), Canada.

Derbyshire, H., Miller, E.R. (1981) The photodegradation of wood during solar irradiation. Part I: effects on the structural integrity of thin wood strips. Holz Roh Werkst. 39:341-350.

Derbyshire, H., Miller, E.R., Turkulin, H. (1995) Investigations into the photodegradation of wood using microtensile testing. Part 1 : the application of microtensile testing to measurement of photodegradation rates. Holz Roh Werkst. 53:339-345.

Derbyshire, H., Miller, E.R., Turkulin, H. (1996) Investigations into the photodegradation of wood using microtensile testing. Part 2: an investigation of the changes in tensile strength of different softwood species during natural weathering. Holz Roh Werkst. 54:1-6.

Derbyshire, H., Miller, E.R., Turkulin, H. (1997) Investigations into the photodegradation of wood using microtensile testing. Part 3: the influence of temperature on photodegradation rates. Holz Roh Werkst. 55:287-291.

Evans, P.D., Banks, W.B. (1988) Degradation of wood surfaces by water. Changes in mechanical properties of thin wood strips. Holz Roh Werkst. 46:427-435.

Evans, P.D., Banks, W.B. (1990) Degradation of wood surfaces by water. Weight losses and changes in ultrastructural and chemical composition. Holz Roh Werkst. 48:159-163.

Evans, P.D., Schmalzl, K.J. (1989) A quantitative weathering study of wood surfaces modified by chromium VI and iron III compounds. Part 1: loss in zero-span tensile strength and weight of thin wood veneers. Holzforschung 43:289-292.
Evans, P.D., Mitchell, A.J., Schmalzl, K.J. (1992) Studies of the degradation and protection of wood surfaces. Wood Sci. Technol. 26:151-163.

Evans, P.D., Thay, P.D., Schmalzl, K.J. (1996) Degradation of wood surfaces during natural weathering. Effects on lignin and cellulose and on the adhesion of acrylic latex primers. Wood Sci. Technol. 30:411-422.

Faix, O., Grünwald, C., Beinhoff, O. (1992) Determination of phenolic hydroxyl group content of milled wood lignins (MWLs) from different botanical origins using selective aminolysis, FTIR, ${ }^{1} \mathrm{H}-$ NMR, and UV spectroscopy. Holzforschung 46:425-432.

Gurnagul, N., Page, D.H. (1989) The difference between dry and rewetted zero-span tensile-strength. Tappi J. 72:164-167.

Haider, K., Domsch, K.H. (1969) Abbau und Umsetzung von lignifiziertem Pflanzenmaterial durch mikroskopische Bodenpilze. Arch. Microbiol. 64:338-348.

Harrington, K.J., Higgins, H.G., Michell, A.J. (1964) Infrared spectra of Eucalyptus regnans f. Muell. and Pinus radiata d. Don. Holzforschung 18:108-113.

Hartley, C. (1958) Evaluation of wood decay in experimental work. In: Report of the Forest Products Laboratory, No. 2119. Forest Products Laboratory, Madison, WI.

Ifju, G. (1964) Tensile strength behaviour as a function of cellulose in wood. Forest Prod. J. 14:366-372.

Kersavage, P.C. (1973) Moisture content effect on tensile properties of individual douglas-fir latewood tracheids. Wood Fiber 5:105-117.

Kollmann, F. Technologie des Holzes und der Holzwerkstoffe. Springer Verlag, Berlin, 1951.

Law, K.N., Garceau, J.J., Koran, Z. (1977) Measurement of intraincrement tensile strength by using a zero-span technique. Wood Sci. 10:42-48.

McGill, R., Tukey, J.W., Larsen, W.A. (1978) Variations of box plots. Am. Stat. 32:12-16.

Raczkowski, J. (1980) Seasonal effects on the atmospheric corrosion of spruce micro-sections. Holz. Roh. Werkst. 38:231-234.

Turkulin, H., Sell, J. (2002) Investigations into the photodegradation of wood using microtensile testing - Part 4: tensile properties and fractography of weathered wood. Holz. Roh. Werkst. 60:96-105.

Turkulin, H., Derbyshire, H., Miller, E.R. (2004) Investigations into the photodegradation of wood using microtensile testing. Part 5: the influence of moisture on photodegradation rates. Holz. Roh. Werkst. 62:307-312.

Winandy, J.E., Rowell, R.M. (1984) The chemistry of wood strength. In: The Chemistry of Solid Wood. ACS Symposium Series 208. Ed. Rowell, R.M. American Chemical Society, Washington, DC. pp. 211-255.

Xiao, Z., Xie, Y., Militz, H., Mai, C. (2010) Effects of modification with glutaraldehyde on the mechanical properties of wood. Holzforschung 64:483-488.

Xie, Y., Krause, A., Militz, H., Turkulin, H., Richter, K., Mai, C. (2007) Effect of treatments with 1,3-dimethylol-4,5-dihydroxyethyleneurea (DMDHEU) on the tensile properties of wood. Holzforschung 61:43-50.

Xie, Y., Xiao, Z., Goodell, B., Jellison, J., Militz, H., Mai, C. (2010) Degradation of wood veneers by Fenton's reagents: effects of wood constituents and low molecular weight phenolic compounds on hydrogen peroxide decomposition and wood tensile strength loss. Holzforschung 64:375-383.

Received July 22, 2011. Accepted November 1, 2011.

Previously published online December 13, 2011. 